\title{
Pengantar Editor: Relasi Etnisitas di Bali
}

$\int u$

urnal Kajian Balil edisi ini tampil dengan tema relasi antaretnis di Bali. Topik ini diwakili dua artikel yang dimuat di awal, keduanya menunjukkan dinamika dan kompleksitas hubungan antaretnis di Bali. Lokasi penelitiannya, satu di Pupuan Tabanan antara etnis Bali dengan Tionghoa, sedangkan satu lagi di Petang, Badung, antara etnis Bali dengan etnis Bugis.

Kajian relasi antaretnis di Bali bukan pertama kali ini terjadi, tetapi sudah sering dilaksanakan dan dipublikasikan para peneliti. Misalnya, buku Integrasi Budaya Tionghoa ke dalam Budaya Bali dan Indonesia (Sebuah Bunga Rampai) (2011) yang disunting Sulistyawati dkk adalah salah satu contohnya. Buku ini memuat sebelas karangan yang mengulas interaksi dan relasi antara etnik Bali dengan Tionghoa dan etnis lainnya. Buku lain adalah Between Harmony and Discrimination: Negotiating Religious Identities Within Majority-Minority Relationships in Bali and Lombok (2011) disunting oleh Brigitta Hauser-Schäublin dan David Harnish juga membahas relasi antara golongan berbeda etnik dan agama di Bali. Akan tetapi, artikel yang muncul dalam jurnal ini memiliki objek penelitian dan sudut pandang yang berbeda sehingga dapat dikatakan memperkaya kajian tentang relasi antaretnik di Bali pada khususnya dan Indonesia pada umumnya.

Kajian mengenai hubungan antaretnis di Bali tidak saja membahas dinamika hubungan antara dua atau lebih kelompok dengan latar belakang berbeda (agama, suku, ras, antargolongan) tetapi juga menyiratkan bahwa Bali bukanlah pulau dengan komunitas dan budaya yang homogen. Fakta menunjukkan keragaman etnik dan budaya di Bali. Hanya saja, dominannya etnik dan budaya Bali, dalam kesatuan pulau dan satu provinsi, membuat citra homogen Bali lebih kuat daripada citra heterogen. Dalam edisi kali ini, terdapat sejumlah artikel yang membahas secara kritis heterogenitas masyarakat, komunitas, dan budaya Bali. Semuanya menyarankan bahwa persepsi Bali sebagai satu pulau dengan budaya yang homogen adalah mitos. 
Pembahasan topik relasi antaretnis senantiasa relevan sepanjang waktu, terutama dewasa ini, ketika Indonesia tidak henti-hentinya menghadapi wacana-wacana dan fenomena yang mengancam harmoni sosial. Di Indonesia pernah terjadi beberapa kali konflik antaretnik, seperti di Sumatra, Kalimantan, Sumbawa, dan Papua. Usaha meredam terus terjadi, tetapi tidak menutup kemungkinan terjadi lagi. Masyarakat termasuk tentunya kalangan intelektual sepatutnya mengkaji dinamika, harmoni, atau kesenjangan hubungan antaretnik sehingga bisa memperkaya persepsi untuk membangun kehidupan sosial yang berdampingan dengan lebih baik. Kajian-kajian berlanjut dapat meningkatkan pemahaman dan mencegah konflik terbuka atas nama kedewasaan intelektualitas.

Dua artikel yang membahas hubungan antaretnik di Bali secara kritis dalam edisi ini disumbangkan oleh IGusti Made Aryana lewat tulisan "Kuasa di Balik Harmoni: Etnografi Kritis Relasi Etnis Tionghoa dan Etnis Bali di Desa Pupuan, Tabanan, Bali" dan Nyoman Suryawan dalam artikel "Kearifan Lokal Sebagai Modal Sosial dalam Integrasi antara Etnik Bali dan Etnik Bugis di Desa Petang, Badung, Bali". Seperti tercermin dari judul masing-masing artikel, keduanya membahas hubungan etnik Bali dengan etnik lain di Bali dalam bentuk relasi yang dinamis. Keduanya menggali nilai dan tradisi lokal yang menjadi perekat yang mengajegkan relasi tersebut dalam dinamika yang berterima.

Tulisan lain dalam edisi ini, dengan topik masing-masing menunjukkan variasi internal masyarakat Bali, yang menyarankan bahwa kesan Bali sebagai masyarakat yang tunggal, homogen adalah berlawanan dengan realitas. I Wayan Ardika, I Ketut Setiawan, I Wayan Srijaya, dan Rochtri Agung Bawono bersama menulis artikel "Stratifikasi Sosial pada Masa Prasejarah di Bali" yang menunjukkan perbedaan 'golongan' masyarakat berdasarkan stratifikasi sosial. Heterogenitas internal ini dibuktikan sudah terjadi sejak zaman prasejarah.

Heterogenitas atau variasi internal juga jelas tampak dalam artikel I Ketut Junitha, Ni Luh Watiniasih, dan Ni Luh Putu Ria Puspitha yang berjudul "Profil Genetika DNA Mikrosatelit Kromosom-Y Masyarakat Laki-Laki Soroh Kayuan Pasek Catur Sanak Bali Mula". Tulisan ini menelusuri gen DNA kelompok 
warga Kayuan, meski demikian, artikel ini mencerminkan bahwa masyarakat di Bali pun terbagi-bagi berdasarkan warga, soroh, atau clan. Pembagian atas soroh ini menambah kompleksitas keragaman etnik Bali. Sama dengan ini, artikel Ni Wayan Radita Novi Puspitasari berjudul "Power and Religion: Geertz Position of Present-Day Bali" yang mengkritisi pandangan Geertz tentang agama Hindu, tetapi di dalamnya juga terungkap perbedaan masyarakat berdasarkan warna/kasta, penanda varasi internal etnik Bali khususnya yang beragama Hindu.

Tulisan Alexander Rankine Cuthbert dan Ayu Suartika yang berjudul "Revisiting Reuter: Symbolic and Material Economies in BaliAga Society" membahas secara kritiskajian penulis sebelumnya, Thomas Reuter, tentang budaya masyarakat Bali Aga khususnya di daerah Kintamani. Di luar tema yang dibahas itu, pembaca yang menyimak tulisan ini juga akan melihat heterogenitas internal etnik Bali. Selain ada Bali modern yang dianggap migrasi dari Jawa, ada juga Bali Aga atau Bali Mula (Bali asli).

Variasi internal tidak saja tampak dari perbedaan subetnik, tetapi juga pengertian tentang budaya. Budaya Bali sering dianggap homogean, satu dan utuh. Mark Hobart dalam artikel kritisnya "Bali is a Battlefield or The Triumph of The Imaginary over Actuality" menunjukkan bahwa budaya Bali jauh dari kesatuan sistem yang tunggal. Menurutnya, kebudayaan bersifat multidimensional yang merupakan tempat berbagai kepentingan diwujudkan, diperjuangkan, ditawar. Dalam situasi demikian, Mark Hobart dengan tepat melabel Bali sebagai 'a battle field' alias 'medan perang' (wacana dan praktik budaya). Dalam medan tempur itu, gagasan dan praktik budaya terus-menerus dalam dinamika untuk mencari dominasi atau pengakuan.

Terima kasih kepada penulis lain yang menyajikan topik kritis dan menarik tentang Bali, yaitu Richard Fox (tentang persepsi perempuan Bali mengenai kontrasepsi dan keluarga berencana), Wayan Artika (tentang reinterpretasi tajen dalam karya sastra dan teks sosial lain), dan Budi Utama (tentang proses pemaknaan cerita rakyat Brayut yang beranak 18 orang). Artikel Richard tentang keluarga berencana dan artikel Budi Utama tentang interpretasi banyak anak menarik dilihat lebih jauh utuk mencari pemaknaan baru atas nilai dan praktik budaya Bali lintas waktu, sesuai konteks zaman, dan dinamika pandangan generasi ke generasi. 
Empat artikel lain, yaitu tentang sistem subak di Tabanan; pariwisata di Blimbingsari, Jembrana; peradilan adat Bali; dan tanaman obat ikut memperkaya Jurnal Kajian Bali edisi ini dengan topik-topik kajian yang berorientasi praktis. Penulis Sumiyati, I Wayan Windia, I Wayan Tika menyumbangkan artikel berjudul "Operasional dan Pemeliharaan Jaringan IrigasiSubak di Kabupaten Tabanan"; Dewa Komang Tantra dan I Wayan Rasna menulis artikel "Diversifikasi Tanaman Herbal Menjadi Produk Minuman untuk Masyarakat Lokal dan Wisatawan"; I Ketut Sudantra, Tjok Istri Putra Astiti, I Gusti Ngurah Dharma Laksana menulis artikel "Sistem Peradilan Adat dalam Kesatuan-kesatuan Masyarakat Hukum Adat Desa Pakraman Di Bali"; dan I Gusti Bagus Rai Utama dan I Wayan Ruspendi Junaedi menyumbangkan artikel "Motivasi Wisatawan Mengunjungi Desa Wisata Blimbingsari, Jembrana, Bali". Apakah artikel berorientasi teoretis atau praktis atau keduanya, tidak menjadi persoalan, yang penting adalah mereka menunjukkan bahwa betapa luasnya area kajian Bali, betapa banyaknya pengetahuan, fenomena, dan wacana yang bisa digarap dalam konteks kajian Bali.

Sebagai penutup, Editor Jurnal Kajian Bali dan segenap tim kerja menyampaikan apresiasi kepada para kontributor atas kerja samanya dalam proses review dan revisi. Juga terima kasih yang tak ternilai kepada para mitra bebestari atas waktu, tenaga, dan keahlian dalam mereview artikel-artikel yang ada. Doa akhir kami adalah semoga kontribusi kita senantiasa berguna bagi kemajuan ilmu pengetahuan khususnya kajian tentang Bali.

Denpasar, 30 April 2017

Editor

I Nyoman Darma Putra 